\title{
PENGARUH PEMBERIAN PERMAINAN SEBAGAI BENTUK \\ PEMANASAN TERHADAP MINAT SISWA DALAM MENGIKUTI PELAJARAN PENDIDIKAN JASMANI
}

\author{
Septyaning Lusianti \\ Penjaskesrek Universitas Nusantara PGRI Kediri \\ septya_lusi@unpkediri.ac.id
}

\begin{abstract}
Abstrak
Penelitian pada permainan sebagai bentuk pemanasan, dengan perlakuan sebanyak empat kali pertemuan, yang bertujuan untuk menarik minat siswa dalam mengikuti pembelajaran pendidikan jasmani. Dalam penelitian ini menggunakan metode eksperimen dengan bentuk desain penelitian Randomized control group Pretestposttest. Dalam pembagian kelompok ada dua yaitu kelompok eksperimen yang diberikan perlakuan berupa permainan sedangkan kelompok kontrol tetap diberikan pemanasan biasa sebagai pembanding.

Analisis datanya dengan Uji $\mathrm{T}$, yang menunjukkan ada hasil perbedaan antara perlakuan (kelompok eksperimen) dan tanpa perlakuan (kelompok kontrol). Hasil uji t paired t-test (uji beda sampel berpasangan) pada: (1) kelompok eksperimen t hitung 12,01 dan nilai t tabel 2,03 (2) kelompok kontrol t hitung 5,44 dan t tabel 2,03. Hasil dari uji $\mathrm{t}$ Independent sample t-test (uji beda sampel kelompok) yaitu thitung 5,0355 dan t tabel 2,0.

Simpulan penelitian bahwa pemberian permainan sebagai bentuk pemanasan dapat meningkatkan minat siswa dalam mengikuti pembelajaran pendidikan jasmani.
\end{abstract}

Kata kunci: Minat, permainan, pemanasan dan pembelajaran.

\section{PENDAHULUAN}

Pendidikan jasmani memegang peranan penting dalam pembentukan manusia seutuhnya. Namun, keberadaan pendidikan jasmani masih dianggap kurang penting dan sering dicap sebagai pembelajaran yang membosankan, jenuh dan dianggap mengganggu perkembangan intelektual anak (Suherman, dalam buku Pendidikan Jasmani Nurhasan, 2005). Ini semua dikarenakan pembelajaran jasmani yang monoton dan gaya mengajar guru pendidikan jasmani serta peralatan yang tersedia kurang memadai. Pada pelajaran pendidikan jasmani siswa yang pasif sering kali duduk saja selama pelajaran berlangsung. Hanya siswa yang senang bergerak yang mengikuti pelajaran dengan senang, sedangkan yang lain berusaha menghindar sehingga ada kesan bahwa pelajaran pendidikan jasmani sangat melelahkan dan hanya cocok untuk anak-anak yang memang menyukai olahraga. 
Untuk mengatasi masalah ini, guru, Departemen Pendidikan dan masyarakat mempunyai tanggung jawab untuk menyelesaikan semua permasalahan ini. Salah satu cara yaitu melalui aktivitas permainan kecil di dalam pemanasan. Dalam pembelajaran penjas, permainan sangat diperlukan untuk meningkatkan minat siswa sebelum menyampaikan materi inti.

"Permainan adalah aktivitas spontan yang timbul apabila fungsi-fungsi badan semuanya normal dan bilamana tidak terdapat gangguangangguan psikis, atau permainan dapat diartikan sebagai suatu sikap jiwa kita, oleh karena pekerjaan kita dapat kita jadikan permainan atau pekerjaan yang benar-benar menjemukan kita (Buchori, 1999:128)."

Jelas sudah apa yang dijelaskan di atas bahwa dengan permainan sesuatu yang membosankan atau menjenuhkan dapat dihilangkan. Buckhori (1999) menjelaskan bahwa "permainan dalam proses pendidikan diperlakukan secara antagonis, dianggap sebagai musuh pendidikan". Hal ini sudah tentu menjadi tanggung jawab lembaga pendidikan untuk menghilangkan pengaruh tersebut, karena jelas dalam sebuah permainan terdapat tujuan yang dimiliki pendidikan jasmani yaitu aktivitas melalui gerak.

\section{Rumusan Masalah}

1. Masih rendahnya tingkat kemampuan mengajar guru Penjas dalam memberikan pembelajaran pada siswa terkait dengan pemberian permainan sebagai bentuk pemanasan terhadap minat siswa dalam pembelajaran Penddidikan Jasmani.

2. Pembelajaran Pendidikan Jasmani belum sepenuhnya dilaksanakan secara efektif.

Tujuan

Untuk memperbaiki kinerja guru dalam proses pembelajaran Pendidikan Jasmani terkait dengan permainan sebagai bentuk pemanasan terhadap minat siswa dalam pembelajaran Pendidikan Jasmani.

Asumsi

Dalam penelitian ini peneliti berasumsi bahwa semua murid kelas $\mathrm{XI}$ SMU Negeri 1 Sumenep-Madura memperoleh materi pembelajaran Permainan sebagai bentuk pemanasan.

1. Hipotesis

Dalam penelitian ini peneliti berasumsi bahwa semua murid kelas XI SMU Negeri 1 Sumenep-Madura memperoleh materi pembelajaran Permainan sebagai bentuk pemanasan.

2. Bahan dan metode

A. Jenis dan Desain Penelitian 
Jenis penelitian yang digunakan adalah komparatif yaitu penelitian yang di arahkan untuk membandingkan satu kelompok sampel dengan kelompok lainnya (Maksum, 2006 : 42).

Sedangkan desain penelitian yang digunakan adalah metode eksperimen dengan bentuk desain Randomized Control Group Pretest-Posttest.

B. Variabel Penelitian

Variabel bebas $\quad$ : Pemberian permainan sebagai bentuk pemanasan.

Variabel terikat : minat siswa mengikuti pelajaran pendidikan jasmani.

Bentuk desain Randomized Control Group Pretest-Posttest dengan pola sebagai berikut :

\begin{tabular}{rlll}
\hline Variabel bebas & To & $X$ & T1 \\
\hline Variable terikat & To & - & T1 \\
\hline
\end{tabular}

$\begin{array}{ll}\text { Keterangan: } & \\ \text { Variabel bebas } & =\text { pemanasan dengan permainan } \\ \text { Variabel terikat } & =\text { pemanasan tanpa permainan } \\ \text { T0 } & =\text { pre-test } \\ \text { X } & =\text { perlakuan } \\ \text { T1 } & =\text { post-test }\end{array}$

C. Populasi dan Sampel

Populasi yang digunakan adalah semua siswa baik laki-laki maupun perempuan kelas XI SMA Negeri 1 Sumenep Madura yang terdiri atas delapan (8) kelas, dimana setiap kelas siswanya berjumlah 40 siswa maka jumlah keseluruhan populasi berjumlah 320 siswa.

Peneliti mengambil sampel sebesar $25 \%$, maka dari 320 siswa menjadi 80 siswa yaitu sebanyak 2 kelas. Setelah terpilih 2 kelas peneliti juga akan mengundinya lagi untuk mencari kelas kelompok eksperimen dan kelas satunya sebagai kelompok kontrol.

Tehnik sampling yang digunakan adalah tehnik cluster random sampling, dimana setiap populasi memiliki peluang yang sama untuk terpilih menjadi anggota sampel dengan cara acak atau undian. Dalam cluster sampling yang dipilih bukan individu melainkan kelompok atau area. Alasan penulis mengambil tehnik ini karena semua populasi mempunyai hak yang sama untuk menjadi sampel penelitian serta tidak terdapat perbedaan untuk menjadikan kelompok kontrol dan kelompok eksperimen karena pemilihannya secara acak atau undian. 


\section{Tehnik Pengumpulan Data}

Tehnik pengumpulan data yang digunakan dalam penelitian ini adalah dengan melakukan kelompok eksperimen dan kelompok kontrol yang sama-sama diberikan pre-test dan post-test serta instrumen yang digunakan adalah angket (skala likert).

E. Tehnik Analisis Data

Tehnik analisis data yang di pergunakan yaitu T-test atau uji T yang artinya tehnik statistik yang dipergunakan untuk menguji signifikansi perbedaan dua buah mean yang berasal dari dua buah distribusi dengan melalui

1. Uji beda rata-rata untuk sampel berpasangan (Paired sampel t Test)

a. Kelompok Eksperimen

$$
\begin{aligned}
& \mathrm{t}=\frac{M X_{1.2}-M X_{1.1}}{s d_{1} / \sqrt{n}} \\
& \mathrm{sd1}=\sqrt{\frac{n \sum d_{1}^{2}-\left(\sum d_{1}\right)^{2}}{n(n-1)}}
\end{aligned}
$$

b. Kelompok kontrol

$$
\mathrm{t}
$$

$$
=\frac{M X_{1.2}-M X_{1.1}}{s d_{1} / \sqrt{n}}
$$

sd2

$$
=\sqrt{\frac{n \sum d_{1}^{2}-\left(\sum d_{1}\right)^{2}}{n(n-1)}}
$$

keterangan :

$$
\begin{array}{ll}
\text { MX1.2 } & =\text { Rata-rata pre-test } \\
\text { MX1.1 } & =\text { Rata-rata post-test } \\
\mathrm{Sd} & =\text { standart deviasi } \\
\mathrm{N} & =\text { jumlah sampel }
\end{array}
$$

2. Uji beda rata-rata antar kelompok (Independent sample test)

$$
\mathrm{t}=\frac{M X_{1}+M X_{2}}{\sqrt{\frac{s d_{1}}{n}+\frac{s d_{2}}{n_{2}}}}
$$

keterangan :

$$
\text { MX1 = Rata-rata kelompok eksperimen }
$$




$$
\begin{array}{ll}
\mathrm{MX2} & =\text { rata-rata kelompok kontrol } \\
\mathrm{Sd1} & =\text { Standart deviasi kelompok eksperimen } \\
\mathrm{Sd} 2 & =\text { Standart deviasi kelompok kontrol } \\
\mathrm{N} & \text { = Jumlah sampel } \quad \text { (Sugiyono, 2005:134) }
\end{array}
$$

F. Hasil

Tabel 4.1. Deskripsi Hasil Kelompok Eksperimen

\begin{tabular}{llll}
\hline Deskripsi & Pre-test & Post-test & Beda \\
\hline Jumlah Sampel & 40 & 40 & 40 \\
\hline Rata-rata & 119,625 & 144,375 & 24,75 atau 20,69\% \\
\hline $\begin{array}{l}\text { Standart } \\
\text { Deviasi }\end{array}$ & 6,452 & 11,555 & 5,103 \\
\hline Varians & 41,625 & 133,522 & 91,897 \\
\hline Nilai maksimum & 131 & 170 & 22 \\
\hline Nilai minimum & 109 & 111 & 59 \\
\hline
\end{tabular}

Dari tabel $4.1 \mathrm{di}$ atas dapat diketahui bahwa rata-rata nilai hasil pengisian angket tentang minat siswa pada kelompok eksperimen sebelum penerapan permainan sebagai bentuk pemanasan (pre-test) sebesar 119,625 dengan varians 41,625, standart deviasi 6,452, serta nilai tertinggi 131 dan terendah 109. untuk hasil sesudah penerapan permainan sebagai bentuk pemanasan (post-test) rata-rata yang diperoleh 144,375 dengan varians 133,522: standart deviasi 11,555 , serta nilai tertinggi 170 dan terendah 111. Nilai beda antara pre-test dan post-test adalah rata-rata yang diperoleh 24,75 dengan varians 91,897 dan standart deviasi 5,103 serta nilai tertinggi yaitu 22 dan nilai terendah yaitu 59 .

Dari hasil tersebut dapat dikatakan bahwa ada perbedaan sebesar 24,75 atau $20,69 \%$ antara nilai pre-test dan post-test pada kelompok eksperimen. Hal ini berarti bahwa penerapan permainan sebagai bentuk pemanasan dalam meningkatkan minat siswa dalam mengikuti pembelajaran Pendidikan Jasmani pada kelompok eksperimen ternyata memberikan rata-rata peningkatan yang positif sebesar $20,69 \%$. 
Tabel 4.2 Deskripsi Hasil Kelompok Kontrol

\begin{tabular}{llll}
\hline Deskripsi & Pre-test & Post-test & Beda \\
\hline Jumlah Sampel & 40 & 40 & 40 \\
& & & \\
\hline Rata-rata & 116,20 & 126,75 & 10,55 atau 9,08\% \\
\hline Standart Deviasi & 8,231 & 9,551 & 1,32 \\
\hline Varians & 67,754 & 91,218 & 23,464 \\
\hline Nilai maksimum & 137 & 154 & 40,464 \\
\hline Nilai minimum & 104 & 99 & -5 \\
\hline
\end{tabular}

Dari tabel 4.2 di atas dapat diketahui bahwa rata-rata nilai hasil pengisian angket tentang minat siswa pada kelompok kontrol (Pre-test) sebesar 116,20 dengan varians 67,754 , standart deviasi 8,231 , serta nilai tertinggi 137 dan terendah 104. Untuk hasil sesudah pembelajaran penjas (Post-test) rata-rata yang diperoleh 126,75 dengan varians 91,218 : standart deviasi9,551, serta nilai tertinggi 154 dan terendah 99. Nilai beda antara pre-test dan post-test adalah rata-rata yang diperoleh 10,55 dengan varians 23,464 dan standart deviasi 1,32 serta nilai tertinggi yaitu 40,464 dan nilai terendah yaitu -5 .

Dari hasil tersebut dapat dikatakan bahwa ada perbedaan sebesar 10,55 atau $9,08 \%$ antara nilai pre-test dan post-test pada kelompok eksperimen. Hal ini berarti bahwa penerapan permainan sebagai bentuk pemanasan dalam meningkatkan minat siswa dalam mengikuti pembelajaran Pendidikan Jasmani pada kelompok eksperimen ternyata memberikan rata-rata peningkatan yang positif sebesar $9,08 \%$.

\section{PEMBAHASAN}

Analisis deskriptif dipaparkan untuk menganalisis kesesuaian pengukuran dari hasil pembelajaran permainan sebagai bentuk pemanasan yang dilakukan pada siswa kelas XI SMA Negeri 1 Sumenep Kabupaten Sumenep yang terbagi menjadi dua kelompok yaitu kelompok eksperimen dan kelompok kontrol. Dari hasil penelitian pada kelompok eksperimen dapat disimpulkan bahwa penerapan permainan sebagai bentuk pemanasan pada pembelajaran pendidikan jasmani ternyata dapat meningkatkan minat siswa, hal ini dapat dilihat dari hasil nilai rata-rata posttest lebih besar dari pada nilai rata-rata pre-test. Sedangkan pada 
kelompok kontrol meskipun terjadi peningkatan namun peningkatan tersebut tidak banyak, masih lebih dominan peningkatan hasil rata-rata pada kelompok eksperimen. Hasil secara keseluruhan dari analisis deskriptif adalah bahwa tingkat minat siswa kelompok eksperimen lebih besar dari pada minat siswa pada kelompok kontrol, hal ini terlihat dari nilai beda rata-rata dari kelompok eksperimen lebih tinggi dari nilai beda ratarata dari kelompok kontrol.

\section{KESIMPULAN}

1. Pada Kelompok Eksperimen, nilai rata-rata hasil pengisian angket tentang minat siswa sebelum memberikan perlakuan permainan sebagai bentuk dari pemanasan (Pre-test) sebesar 119,625 dengan standart deviasi 6,452. varians 41,625, Untuk hasil setelah diberikan perlakuan permainan sebagai bentuk dari pemanasan (Post-test) sebesar rata-rata yang diperoleh 144,375 dengan standart deviasi 11,555 dan varians 133,522. Nilai beda antara Pre-test dan Post-test adalah rata-rata yang diperoleh 24,75 dengan standart deviasi 5,103 dan varians 91,897 . Hal ini dapat ditarik sebuah garis besar bahwa pada kelompok eksperimen pemberian perlakuan permainan sebagai bentuk pemanasan memberikan pengaruh peningkatan yang positif sebesar $20,69 \%$ terhadap minat siswa dalam mengikuti pembelajaran penjas.

2. Pada Kelompok Kontrol, nilai rata-rata hasil pengisian angket tentang minat siswa dalam pembelajaran penjas (Pre-test) sebesar sebesar 116,20 dengan standart deviasi 8,231 dan varians 67,754 . Untuk hasil sesudah pembelajaran penjas (Post-test) rata-rata yang diperoleh 126,75 dengan standart deviasi 9,551 dan varians 91,218. Nilai beda antara Pre-test dan Post-test adalah rata-rata yang diperoleh 10,55 dengan standart deviasi 1,32 dan varians 23,464. Hal ini dapat ditarik sebuah garis besar bahwa pada Kelompok Kontrol, memberikan pengaruh peningkatan yang positif namun tidak terlalu besar sebesar 9,08\% terhadap minat siswa dalam mengikuti pembelajaran Pendidikan Jasmani.

\section{DAFTAR PUSTAKA}

Arikunto, Suharsimi. (2006). Prosedur Penelitian Suatu Pendekatan Praktik. Jakarta : Asdi Mahasatya.

Direktorat Pendidikan Guru dan Tenaga Teknis. (1979). Permainan dan metodik.Bandung : Departemen Pendidikan dan Kebudayaan.

Djaali. (2007). Psikologi Pendidikan. Jakarta : PT. Bumi Aksara. 
Djamarah, Syaiful Bahri. (2002). Psikologi Belajar. Jakarta : Rieneka Cipta.

Hadi, Furqon. (2007). Pengaruh pemberian permainan kecil di dalam pemanasan terhadap minat siswa dalam pembelajaran bola basket. Skripsitidak diterbitkan. Surabaya : FIK UNESA.

Paul Uram. (1986). Latihan Peregangan. Terjemahan oleh Iskandar \& Engkos Kosasih. Jakarta : AKADEMIKA PRESINDO.

Hurlock, Elizabeth.B. (1942) (edisi keenam). Perkembangan anak. Jakarta : Erlangga.

Hurlock, Elizabeth.B. (1997) (edisi keenam). Perkembangan anak. Jakarta : Erlangga

Lutan, Rusli, Rusli Ibrahim, dkk. (2002). Supervisi Pendidikan jasmani : konsep dan praktik. Jakarta : Bagian proyek pembinaan kelas olahraga.

Maksum, Ali dkk. (2006). Metodologi Penelitian, Surabaya.

Maksum, Ali dkk. (2007). Statistik Dalam Olahraga, Surabaya

Martini, (2005). Proedur dan Prinsip-prinsip Statistika. Surabaya : UNESA University Press.

Michael J. Alter, MS. Tanpa tahun. 300 teknik peregangan olahraga. Terjemahan oleh Jamal habib. 1996. Jakarta : PT RajaGrafindo Persada.

Mustaqim dan Abdul wahib. (2003). Psikologi Pendidikan. Jakarta : Rieneka Cipta.

Nurhasan, dkk. (2005). Petunjuk Praktis Pendidikan Jasmani. Surabaya : UNESA University Press.

Soejanto, Agoes. (2005). Psikologi Perkembangan. Jakarta : Rieneka Cipta.

Soewondo, Soetinah. (1993). dasar-dasar Pendidikan. Semarang : Effhar Publishing.

Sukintaka. (2004). Teori Pendidikan jasmani. Bandung : Yayasan Nuansa Cendekia.

Syah, Muhibbin. (2008). Psikologi Pendidikan dengan Pendekatan Baru. Bandung : : PT remaja Rosdakarya.

Tedjasaputra, Mayke S. (2003). Bermain, Mainan dan Permainan. Jakarta : PT.Grasindo. 
Tim tujuh. (2006). Payung Penelitian pendidikan jasmani pendidikan ilmu keolahragaan UNESA, Surabaya. 